\title{
Lowering Boats at sea
}

\section{W. Stirling Lacon Esq.}

To cite this article: W. Stirling Lacon Esq. (1873) Lowering Boats at sea, Royal United Services Institution. Journal, 17:71, 97-112, DOI: 10.1080/03071847309417794

To link to this article: http://dx.doi.org/10.1080/03071847309417794

\section{册 Published online: 11 Sep 2009.}

Submit your article to this journal

Џll Article views: 5

Q View related articles $\longleftarrow$ 


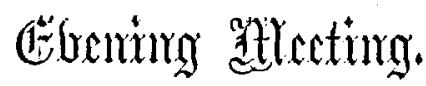

Monday, February 3rd, 1873.

AdMIRal GEORGE ELLIOT, in the Chair.

NAJES of IIEJIBERS who joined the Institution between the 2Sth Januars and the 3rd February, 1873.

LIFE.

Perey, Lord Algemon, M.A., Licut. Greniadier Guards.

ANNUAL.

Braddock, Lionel F., Capt. 1st Surrey Anderson, J., Licut. London Scottish Artillery Foluntecrs.

Falmasser, Ernest B., Ensign 22nd Middlesex Rille Volunteers.

Trench, Fredk., Capt. 20th. Hussars, F.R.G.S.

Legge, Hon. Henry C, Lieut. Coldstream Guards.

Bromne, W.IY.,Lieut. Bengal Staff Corps. Crommelin, W. A., Colonel R.E.

\section{LOWERING BOATS AT SEA.}

\section{By W. Striming Llacon, Esq.}

Ix consequence of the accident involving loss of life which happened to the boats of Hor Majesty's ship "Ariadne," in 1872, the subject was taken ap in the House of Commons, and after debate, and strong expression of opinion by various Members, on the motion of Mr. Bourerie, the question was referred to the Lords Commissioners of the Admiralty, who "decided to appoint a Committee to inquire into the "question of the supply of life-boats to the Navy, the best lowering "apparatus adapted to the special services which men-of-war have to "perform, and generally into the best means of saving life at sea, "always bearing in mind the special character of Her Majesty's ships." The scope of the enquiry being thus limited (although two ont of seven members of the Committee were appointed from the Merchant Service), the Committee reported upon the three plans which hare been in use, or tried in Her Majesty's Nary-namely, Clifford's, Kynaston's, and the ordinary service plan. With regard to Clifford's, the report says, "Mrany failures, due to thie appa"ratus, hare occurred in lowering boats so fitted, and the Com"mittee are therefore unable to recommend its adoption in Her Ma" jesty's Nary." With regard to Kynaston's, the report says, "Though 
"there are some instances recorded in which they hare not acted satis"factorily, still they so nearly meet the conditions required, that the " Committee feel justified in recommending their further supply to $\mathrm{Her}$ "Majesty's ships. At the same time they are unable to recommend "their use bing made compulsory on Officers who are unwilling to "adopt them." And as to the ordinary service plan, the report says, "The eridence does not record the loss of a single life to Her Majesty's "Service attrilutable to this fitting," although the witnesses examined " must have referred to an experience of many hundred instances of "its use at sea. It possesses the advantage of simplicity, and enjoys " the entire confidence of many experienced Officers, whose judgment " is supported by the large success which has attended its nse- a fact " confirmed by the evidence; the Committee are therefore of opinion "that this is the most satisfactory mode extant of lowering boats at "sea." And further, "The Committee cannot recommend any of the "inventions for lowering boats at sea by mechanical means, which have "been brought before them."

Having twice lectured at this Institution on this question, and having for the last twenty jears endearoured to direct public attention to the subject, I appeared, and gave' evidence before this. Committee. But a gallant Admiral writes to me, "Your evidence is so giren in the Blne Book, that it is impossible to make ont what jou mean." And it is so. I saw (I think I may say so) that there was but little disposition to accept the information which $I$ was desirous of putting before the Committce, and the drawings which I was requested to send in, were not published with the others, but were. handed over to the Admiralty, when the Committee broke up. Tho Admiralty have since deposited them in this Institution at my request.

I was desirous of recording information that might be useful to the public generally, but I was told "that the Committee wished to con"fine themselves to the Navy." But I could have given information that might be uscful to the Nars, had I boen so permitted. The report of the Committee says, that "the last accident appears to have been “ in 1835, to Her Jajesty's ship 'MTelville, off the Cape of Good "Hope, in bad weatluer, when both cutters were lovered successfully, "by common tackles for the rescue of an Officer and man overboard." But the following stands recorded in the Joumal of this Institution :Before the delivery of my lecture liere on June 9th, 1858, I wrote to General Willes for the particulars of this melancholy case, he having been on board at the time, and he enclosed to me the following letter from Captain A. S. Hammond, R.N. :- "On the occasion of Sir John Gore's "son being drowned off the Cape of Good Hope on the 30th of April, " 1835 , thic 'Melville," 74 guns, on board of which ship the Admiral's " flag was flying, was lying to, under a maintop-sail. The courses "were being hauled up, and topsails lowered on the cap, with yards "braced in and secured. A man having fallen overboard from the "weather forcyard-arm, Lieutenant John Gore, the flag licutenant, " jumped overboard to save him from the weather-quarter boat; and "soon afterwards the lee-quarter boat was cleared away and lowered,

* The italics are mine.-W. S. I. 
" with Lieutenant Fitzgerald and ten men in her, at which operation I " attended. But in spite of every attention, from the heary lurching " of the ship, and her rolling to windward, a considerable quantity of " water was shipped by her; and I am also of opinion that the boat was "shaken by the blows which she received in striking against the ship's " side in the act of lowering. In consequence of this impression, I " spoke to the Captain (the present Rear-Admiral Sir Henry Hart, "K.C.B.), and asked him if I might-be allowed to take the weather " quarter cutter, in case of any disaster having happened to the other "boat, to which request he gare his consent, and I jumped into her, "quickly followed by numerous volunteers, and a joung middy of the " name of Heath."

Gentlemen, I must here be allowed to pause. I also was a midshipman in those days, and $I$ - dined on board the "JIelville" at Sangor, and sat at the same table with Lieutenant Gore; and probably saw many of the unfortunate men who were drowned; the other midly was the present gallant Admiral Sir Leopold Heath, the Senior Naral Officer of the Absssinian Expedition.

The letter goes on to say-

"Any amelioration of the established plan of lowering boats would, " in this instance, lave been of infinite service: for I have never " witnessed a worse oceasion for lowering a boat during my experience " at sen. From the weight of the men in her, and the constant lurching " of the ship, we were nearly thrown out of the boat frequentls, and I "thought she would have been stove in from striking against the " mnzzles of the main deck guns; and before we could get the trickles " unhooked, the indraught took us under the counter, and we had the " nearest escape possible from being swamped by it. Fortunately we " managed to get clear of the ship withont mishap, and proceeded on "our search, which proved, alas! a most fruitless ope, as all hands were "lost except ourselres. Don't jon recollect," continues the writer, "when a man fell overboard from us, just after leaving the Sand"Heads, and a quarter boat was lowered with, I think, Crawfurd in " her, and the boat's crew, and something liappeped to the boat's tackle"falls in lowering, and the whole of the men were thrown into the "water, and they also went astern, together with the swamped boat, "oars, bottom boards, \&c., floating about. Fortunatels no lires were "lost, but there might have been."

I quote again from the Journal of this Institution :-

On Saturday, the 20th of Norember, 1804, the English fleet, nnder "the command of Admiral the Honourable W. Cormwallis, lay at "anchor in 'Torbay; as it was late in the jear", and the night dark and "stormy, orders were giren for" the flect to put to sea. Unfortunately " in fishing the anchor of the "Venerable," 74 guns, the fisli hool "gave way, and a man was precipitated into the sea. The alarm was " immediately given, and one of the cutters was grdered to be lowered. "Numbers of the crew rushed aft to carry the orders into effect; but " in the confusion one of the falls was suddenly let go, the boat fell by " the run, filled, and a midshipman and two of the men were drowned.

"In a few minutes another boat was lopered, which fortunately suc- 
" ceeded in picking up the man who first fell overboard. Orring to " this delny, the 'Venerable' fell off considerably towards Brixhan, "and getting stern way, was unable to weather the Berry Head. "Every effort was made to stay her, but the ship refused; and not " having room to wear, she drove on shore at the nortl part of the bay, " on a spot called Roundem Head, near Paignton. In sixtecn hours "from the time she first struck, the whole ressel had disappeared "under the action of the raging surf, lashed into fury by the violence " of the gale. The crew consisted of 590, of whom a few were "drowned."

Again,-

"The 'Arenger,' a steam frigate, Captain Charles Napier, with an "armament of six heary guns and a crew of 250 men, sailed from "Gibraltar on the 17th of December, 1847. At 9 P.x. on the 20th of "December, while running with square yards at the rate of eight or " nine knots, she struck upon the Sorelli. The officers in the gun-room " were upon the point of retiring to their berths when they were startled "by a sudden jerk; the ship gave a heavy lurch, as if filling, and her "whole frame appeared shaken, and evory beam loosened. The " Captain then gave the order 'out boats;' these were his last words, "for he was immediately afterwards washed orerboard and drowned. "Whilst they were in the act of lowering the cutter, an accident " occurred which was nearly proving fatal to all their hopes of preser"vation; in lowering the boat, the foremost fall got jammed, and the " after one going freely, the boat had her stern in the water and her "bows in the air. At this moment Dr. Steel threw in his cloak, " which fortunately got into the sheave-hole of the after fall and stopped "it. Just as the boat tonched the water, and before the tackles were " unhooked, the ship again struck heavily, and began. swinging broad" side to the sea, falling over to starboard at the same time, which, "from the cutter being the port one, made her crash with great violence " against the ship's side. However, by dint of great exertion, the boat " was got clear from the tackles, and pulled clear from the ship. Of a " crew of 250,246 were drowned." .

The report of the Committee states "the evidence is remarkable for " establishing the fact that comparatively few accidents inrolving loss " of life have occurred in Her Mlajesty's Nary to boats lorrered at sea." How far this report may be satisfactory to the House of Commons, by whom the inquiry was instigated, remains to be seen. I can only regret that two of the Members of the Committee were unavoidably absent the day I gave my evidence, namely, the Duke of Edinburgh and Sir James Anderson. Of His Royal Highness it would be presumption in me to speak; but the man who conducted the brilliant enterprise of picking up the Atlantic cable, an exploit worthy of the genius of a great maritime country, is not the man to shelre any question that might be useful to the profession of which he is so distinguished a member.

Before passing on, I must be permitted to give opinions and facts other than those appertaining to the Navy, with regard to a system, an amelioration of which the House of Commons has expressed itself so 
desirous of obtaining. The following is recorded by the Religious Tract Society, after the loss of the "Kent" by fire in the Bay of Biscay :-

"Although Captain Cobb had used every precaution to diminish "the danger of the boat's descent by stationing a man with an axe to "cat away the tackle from either extremity, should the slightest diffi"culty occur in unlooking it; yet the peril attending the whole "operation, which can only be estimated by nautical men, had rery " nearly proved fatal to its numerous inmates. After one or two " unsuccessful attempts to place the little frail bark fairly upon the " surface of the water, the command was given to unhook. The tackle " at the stern was, in consequence, immediately cleared; but the ropes " at the bow having got foul, the sailor there found it impossible to " obey the order. In vain was the axe applied to the entangled tackle, "the moment was inconceivably critical, as the boat, which necessarily "followed the motion of the ship, was gradually rising out of the " water, and must in another instant have been hanging perpendicularly " by the bow, and its helpless passengers launched into the deep, had " not a most providential wave suddenly struck and lifted up the stern, " so as to enable the serman to release the tackle."

In the case of the Royal Mrail steamship "Amazon," one of the survirors states:-

"The mail boat, when lowered, was immediately swamped with about "twenty-fire people in her, all of whom were lost. The pinnace, when "lowered, sheered across the sea before the people in her could unhook " the fore tackle; they were thereby washed ont, and the boat remained. " hanging by the bow. While clearing away the second cutter, a sea " struck her and raised her off the cranes, and unhooked the bow " tackle. The fore end immediately fell down, and the people in her " (with the exception of two, who hung doubled over the thwarts), were "precipitated into the sea." Lieutenant Grylls, R.N., stated :-

"The first boat attempted to be lowered was on the port quarter. "Lieutenant Grylls was himself lowering the after-fall, when Captain "Symons seized him by the arm, and besought him to desist, as he said "cverybody would be drowned. Lieutenant Grylls then called out to " the person by the foremost fall, imploring him not to lower, as the ship "was going so fast. The person at the foremost fall, by constant and " urgent request of the people in the boat, let the fall go, by which " means the boat turned over, and, as nearly as could be seen, crery one " was washed out of her. Seeing this at the moment, Lieutenant "Grglls attempted to let go the after-fall, so as to save them; but the "fall being jambed, and having fouled, and the boat thus not being " clear, her stern hung in the air for the moment, until cut adrift by " some one, when she turned over, and, seeing the people washed "away, Lieutenant Grylls turned aside from the appalling sight in " horror." Mr. Neilson states :-

"In the meantime, the aftermost boat on the port side (I think the " mail boat) was lowered down, with probably twenty-five people in "her; but the moment she touched the water she swamped, and all 
"hands that were in her drifted. astern, all clinging together with "dreadful shrieks. The next boat forward (the pinnace) was also "lowered full, but by some accident the after tackle alone got unhooked, " and she was dragged forward by the foretackle with such rapidity " that the sea swept round her sides, and washed erery soul ont of her. "At this time the second cutter had renched the water, when a sea "struck the bow, and as the ship rose from the swell of the waves, she "lifted the boat perpendicularly by the stern tackle, and discharged "all the unfortunate inmates but two, who hung shrieking across the "thwarts."

William Angus says:-

"In attempting to lower another boat on the starboard side (the first "cutter), the stern fall was let go too quickly, and on dipping into the "water, the boat was drawn to the side of the ship, and the people "thrown into the sea."

Isaac Roberts stated :-

"In lowering her down, unfortunately he let go the fore tackle, and "threw the people, about eighteen or twenty, crew and passengers, into "the water."

George Webb says :-

"The Chief Officer, and several others, were clearing away the after" most lifeboat. He jumped into her, and got hold of the tackle, and "lowered her down. Some one else lowered the bow. Before the boat " touched the water, the after tackle fouled, and he took out his knife "and cut it."

Henry Wright says :-

"When in the bont, preventing her from being swamped by trying "to clear the fore tackle fall, the block caught his left hand, and took "off the tops of his two middle fingers, and smashed his little finger;" and Alexander Lang, quartermaster, says "that he went to the wheel, "but it was fonled by the tackle fall of the dingy."

It was a terrible visitation; this ship on fire, in a dark night, galo of wind, and tempestuous sea, tearing along at full speed, without their being able to stop her, and dragging her miserable crew to destruction, and among them the accomplished author of "The Crescent and the Cross ;" but "the Committee entertain grave doubts whether, however admirable "the lowering and disengaging apparatus may be, it is wise to man "and Iower a bont in any considerable sea, while the ship is rapidly "adrancing through the water." But time and tide will wait for no man, nor will the progress of events stand still in order to keep pace with the minds of the Committee. No man in his senses would lower a boat at full speed, if it could be avoided; but if $a$ boat can be lowered safely at full speed, it is erident that she could be lowered safely under other circumstances. Other cases might be quoted, such as the loss of the "Orion" on a fine summer's erening, off the coast of Scotland, where, "while lowering the starboard quarter boat, the bows were "down in the water, while the other end liung by the tackle, and one "or two tumbled out of her; and while the port lifeboat was being "lowered, there were one or two tumbled out of her." Or, in the * The italics are mine.-W. S. L. 
wreck of the "Conqueror," near Boulogne, where " the ladies, children, "and serrants were handed into the cutter; the water was not a couple " of yards off her bottom, but the falls of the tackle had got so entangled " with the rest of the cordage on the poop, that they were not able to "lower them. The Captain cut the boats from the davits."

When I had the honour of conducting the Crown Prince of Prnssia orer this Institution, he did not seem to be so much impressed with the arms or models, as with this theatre. He said, " $\mathrm{Al}$, there is the value of your Institution." It is a fortunate thing for this country that there is some place where such things as I have detailed may be made known. That such things are of the decpest interest to the great steamship companies and the traselling public, I will quote from the lately published work of an American gentleman, "Around the World by Dr. Prime." He says, speaking of the Pacific Jail Steam Company's ship "Japan," 4,35i tons, between San Francisco and Japan and China:-

"The ship carries thirteen large lifeboats, all ready for lannching, " each one capable of floating some fifty persons or more; but it adds "very little, to my sense of security, to see this array of lifeboats. In "those sudden emergencies, which constitnte the chief dangers of the "sen, it is seldom that they are successfully launched, or prove of any " essential service to the mass of the passengers."

The evidence I hare adduced, and the labours of men who for years past have endeavonred to procure an amelioration of the present system (a list of those who have deposited their plans in this Institution is giren at the end of this paper) are sufficient proof of the dangers attending "this ordinary service plan." In using these tackles, it requires two men in the boat, one at each fall to unhook, and on board the ship, two men to lower and two men to clear the falls, no easy matter where the falls are little used, and where, as in the case of the largest merchant steamers, each fall is $\mathbf{2 2}$ fathoms, or 132 feet long (the davits of the "Princess Royal" are 45 feet from the water, consequently the falls must be five or six times that length, or at least from 230 to 270 feet long). Under any circumstances it requires the greatest unanimity of action on the part of these six men; but how is this to be insured during periods of excitement and danger, and during dark nights? If one of the falls should be lowered too quickly, -if one of them should foul, or be accidentally let go, then one end of the boat haring reached the water before the other, it is impossible for the men in the boat to unhook at the same time, and an accident mustineritably happen. Or, supposing that all has gone right on board the ship, and that before the boat has reached the water a sea should lift the stern of the boat and unhook the after tackle, then the boat would sheer across the sea before the people in her could unhool the fore tackle, and they would thereby be washed out, and the boat would remain hanging by the bow; or, if in the act of lowering, a sea shonld strike the bow and anhook the fore tackle, then the fore end would immediately fall down, and the people be precipitated into the sea and drowned. Not only is this operation of lowering boats attended rith so much difficulty and danger, but it is an extraordinary fact that it is in direct opposition to 
any mechanical operation of the like character. It is an acknowledged principle of mechanics that to raise a weight requires a power; but what is gained in power is lost in time. We see it in the erery-day operations of raising a weight, that when the weight has attained the requisite eleration, the power is disconnected, and a break, or other analogous contrirance, is substituted, in order to regulate the descent. Why, therefore, should not the same plan be adopted in the case of weights (i.e., boats) which remain for a lengthened period at the requisite eleration, and which are only required on sudden emergencies? Sailors themselves acknowledge the principle, and carry it into effect, as in the caso of the anchor. When the anchor has been elerated by means of the chain and capstan to the level of the water, a tackle called the "cat" is used to raise it to the lerel of the deck; this is the power, and sailors know rery well that if they were to allow the same to remain, the anchor could never be used on sudden emergencies; they therefore substitute a single rope or chain (called the cathend stopper) and remore the tackle. They remove the one tackle from the anchor; why, therefore, should they not remove the two tackles from the boats, which it has been shown in their use require the greatest unanimity of action? Many Captains of ships have acknowledged the principle, eren in the case of boats, for they have unhooked the tackles and substituted single ropes or pennants; but in doing so, they have aggrarated the disease without substituting a remedy, for, it must be apparent to every one, that if, in lowering with the tackles, there was danger of a heavy bont going down by the run, that danger must be considerably enhanced where the weight has to be balanced and controlled by a single rope.

(I see many landsmen present; I must tell them that sailors are very funny fellows, and have a language of their own. They first cat the anchor, and then they fish it; still Jaick is a character we should do well to cnltirate, for England may rue the day when she turns her sailors into stokers and pokers.)

Through the press I have stated as follows:- "A screw steamship " shall be fitted with four boats on either. side of her, and I will under" take, with one man stationed at each boat, to put all of them, full or " empty, safely and securely into the water, within one minute of the " order being giren to lower, the ship going at full speed." If this is no mere theory or rain boasting, then it will be seen how valuable such an instantaneous system must be in these days of monster ironclads, which, if they do go down, will probably, like the "Captain," go down like a stone, or to the light armour-clad ship, which may be sunk by a shot from one of the monster guns now adopted.

Twenty years ago, the plan which follows was fitted to two of the South Eastern Company's steumers at Folkestone, and in the presence of several thousand people, I, accompanied each time by four men, was lowered six times, the ship going at full speed, or at the rate of $12 \frac{1}{2}$ knots an hour. A certificate, signed by Admiral Sir Edward Tueker, Admiral Hathorn, and twelre other nautical men, testifying to the perfect success of the experiments, was forwarded at the time to the Admiralty; but although, according to the Committee's report, "they have had 


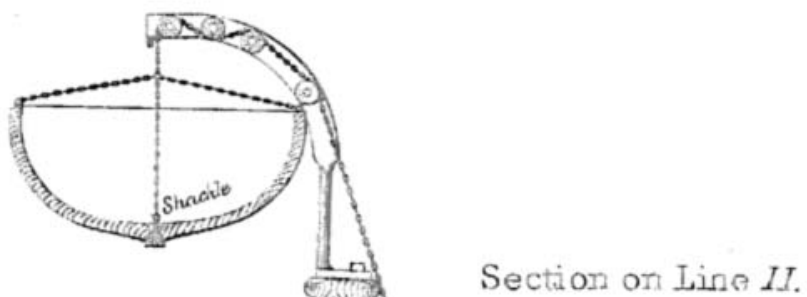

Roller and Davit for small Boats
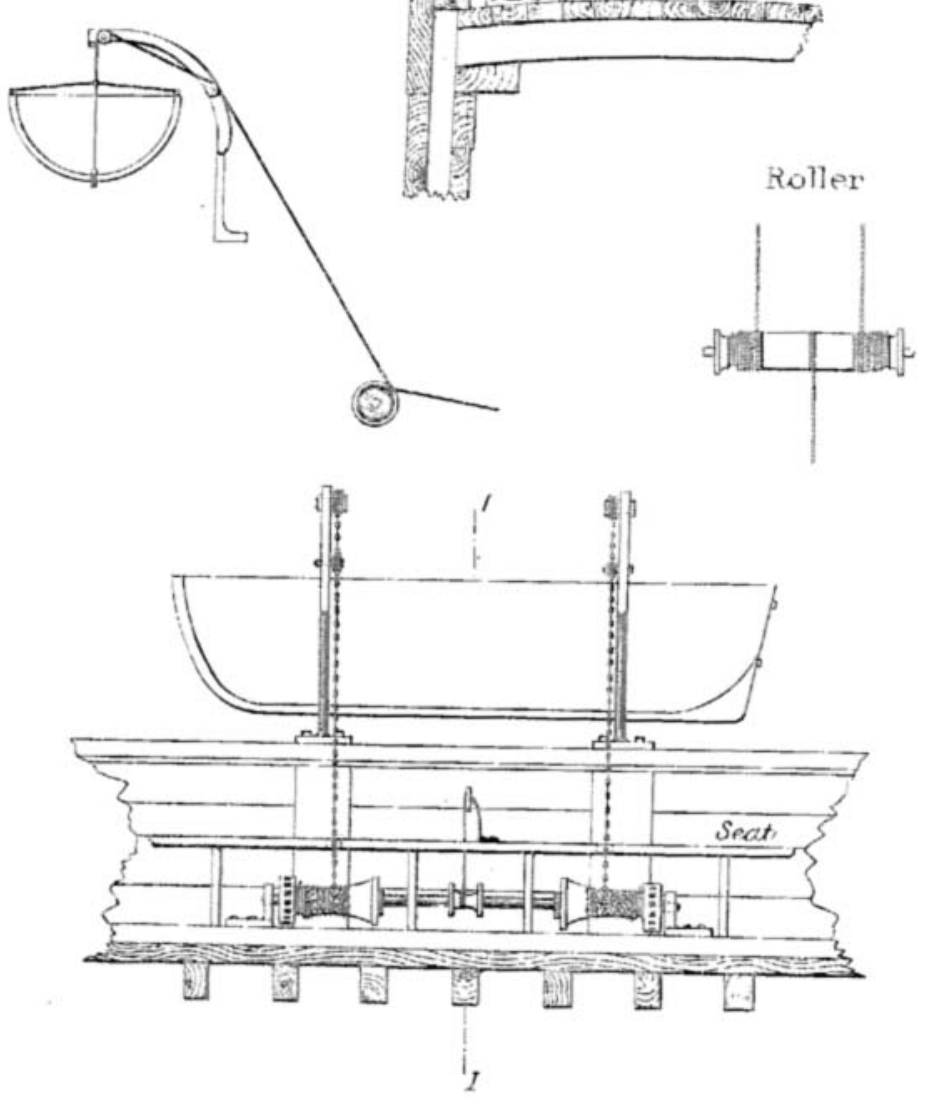
" access to and have examined all the records existing at the Admiralty " since the commencement of 1852, which bear on the questions " referred to them," they hare not considered a plan where such results have been obtained worthy of any other fate than being stowed away at the Admiralty; to be out of sight and out of mind.

I will now describe the plan, of which the engraving on the opposite page is a representation.

\section{The Boat.}

Eyc-bolts are driven through the keel, at the bow and stern, and are clinched. The position of these two eye-bolts will determine the distance apart of the two davits, and the two outer drums to be hereafter mentioned. If the boats are intended to be swung inboard, the cye-bolts must be near the bow and stern of the boat; if not, then they may be nearer towards the centre of the boat.

\section{The Chains or Rope Pennants.}

At one end of each rope pennant or chain is a shackle to attach them to the two eyebolts. Just above the thwarts two smaller chains lead from the main chains, and are attached or hooked to each gunwale to prevent the boat from canting, and at the other end of each chain or pennant is spliced on a length of about 25 feet of lead line with an ejo at either end.

\section{The Davits.}

At the onter end of each davit is an eye-bolt for hooking on the tackles, and in the davits three sheaves, one over or before the other. (If on experiment three sheaves should not be found to be sufficient to control the descent of the heaviest boat, then fire, or the pullejs or sheaves must be placed closer together.)

\section{The Roller or Drums.}

On board the ship is a roller, or three drums attached to each other by an iron bar. To the centre drum, and round which it is coiled, is attached a rope. On one end of each of the outer drums is a groove for receiving the small lines before-mentioned, and a pin on which the eye at the end of each line is to be placed.

When the boat has been hoisted up by the tackles, the ends of the lead lines are passed over and under the sheaves alternately in the davits, and brought inboard and placed over the pins on the drums. By gently pulling upon the centre rope, the drums are made to revolre, the lead lines are coiled in the grooves for their reception, and the chains or pennants packed upon the two outer drums. When the whole has been hove in and set taut, the centre rope is belayed round a belaying pin or cleat, the tackles are unhooked, and the bont is stowed.

The roller or drams may now be boxed in, or, as was done in the caso of the South Eastern Company's steamship "Princess Clementine," covered over with a seat for the passengers. It is worthy of remark that one pair of tackles would be sufficient for all the boats, and these may be kept below, free from the influence of the weather.

FoI. XVII. 
In the drawings, the two onter drums are capstan-headed; this is not necessary for lowering, but on board the "Princess Clementine," two men lioisted up the boat by means of handspikes withont the intervention of tackles.

Care must be taken that the chains or pennants shall be too long, rather than too short, making plenty of allowance for the light and deep draught of a merchant ship.

\section{Lovering.}

One man at the centre rope lowers, and, being on board the ship, can watch the opportune moment to drop the boat into the water. If the boat is lying quietly alongside, the chains or pennants are lowered into the boat by means of the lead lines. If the ship has way on her, the boat will drag away the chains, and they will fall harmlessly into the water. They can now be dramn into the boat, where they will act as ballast; or if the boat is going amay for any length of time, they can be unshackled and left on board the ship. In merchant ships, where the boats hang from the darits for a lengthened period, the use of chains instead of ropes would aroid the necessity of freshening the nip.

I regret that time will not enable me to allude to the rarious plans which hare been brought forward from time to time for "lowering boats at sea," showing at least how much it is a want that is felt by the public; but as my opinion mas asked by the Committee with regard to Clifford's and Kynaston's, I may say that, twelve years ago, I brought forward Olifford's plan in this Institution, because I was desirons that the public should have some.amelioration of the present most dangerous system; but there are these disadrantages attending Clifford's system, the man Iorrering being in the boat cannot see what he is doing, and very likely lets go into the trough of the sea at the very moment when he should not do so, and the boat itself must be disabled by the heary roller which is in her. Kynaston's plan does not do away with the very objectionable method of lowering by the tackles, although a Licutenant told me that he would not use the tackles. I asked him what he meant? He said he should wait till the ship rolled, and then drop the boat on to a sea from the davits. Whether the lifeboat of $\mathrm{Her}$ MIajesty's ship "Serapis" had her bottom knocked in by this method, I am unable to say.

With regard to the "Challenger," her boat was fitted with MIr. Hill's plan, and Neptune did for them what the smart Lieutenant proposed to do with Kynaston's, - a sea struck the bottom of the boat, and disengaged her, whereby she was lost to the "Challenger," and to Her" Majesty's service. Admiral Richards has - written to me that this was through no fault of the system, and I beliere the inrentor claims it, as showing the merit of his plan.

The following plans for lowering boats at sea have been deposited in this Institution, where they may at any time be consulted by persons desirous of obtaining information on the subject :- 
Lacon's (1852).. Journal of the Institution, pamphlet and plan. Clifford's (1857). . Journal of the Institution, pamphlet and model.

Kynaston's .. Pamphlet.

Russell's.. .. Mrodel.

Simpson's $\quad$.. M Model.

Kilner's .. $\quad$.. M Model.

Hill's $\quad$.. .. Jotrnal.

Gentlemen, you must form jour own conclusions from what you have seen and heard. What I wish further to put before you, points the moral of my tale.

The following is taken from the Journal of this Institution, August, 1866 ; it is an extra number, devoted entirely to "The Loss of Life at Sea," in order that the attention of the authorities and of the public might be directed towards it. In February, 1853, the Times, in a leading article, says:- "As the 'Queen Victoria' was lying in the "Lirerpool Docks. last July a gentleman, competent to obserre such "matters," (and when I mention that he is a member of the Council of this Institntion I think it mill entitle him to a favourable consideration at your hands), "noticed that her boats were indeed sound and "spacious, but that they were enreloped in strong canvas, painted "black, and actnally laced below the bottom of the boat, while "the machinery for lowering them was so defective as to be "virtually unserviceable. So absolute indeed was the defanlt of " any proper precautions against sudden accident, that the observer "called one of the seamen to lim and pointed ont the circumstances, "and remarked that the day might come when this inattention to ap"parently small particulars might cost many lives. That day did. "come (within six months), and the lives lave been sacrificed accord" ingly." "The morning was fine and the water smooth. The two "life-boats, which ought to have saved so many, appear to have gone "down with the vessel." (They were not disengaged from her till sixteen hours after the accident.) "The result is that the lives of "fifty-nine persons, including the unfortunate Captain, liave been sacri"ficed."

Of the recent terrible calamity (I refer to the loss of the "Northflect"), I wish to say but few words. The heart of the country has been profoundly stirred, and no words of mine could paint the horrors on the deck of that ill-fated ship daring that amfnl night. But I must point out to you that the ship was lying at anchor, surrounded by other vessels, and the shore-lights at hand; the water was comparatively smooth, and an interval of three-quarters of an hourintervened between the time of the collision and her going down; but of all her boats two only were available, and of these two, one was stove in, and the other cut from the davits ; yet this slip was fresh from Board of Trade inspection; the Emigration Commissioners having very recently been supersęded by the Board of Trade.

You have seen how this plan which I havo submitted to you was treated at the Admiralt5. The Emigration Commissioners refused to I 2 
see it. I offered to submit it to the Board of Trade, or to any persons to be depnted by them; they also declined even to look at it. $M I_{y}$ only object is to make it available for the benefit of the public.

Captain TELIs, R.N:: I should like, Sir, to offer a few remarks upon this lecture which has been an interesting one, and to which we hare all, I am sure, listened with a great deal of attention. But at the same time certain remarks were made about the Committee which, to a great extent were, I think, undescrred. The naval members of that Committee are most distinguished Officers and thoroughly known and appreciated by the whole of the Serrice, and I need not say that the two mereantile Officers are equally distinguished in their relative positions. We hare seen Mr. Stirling Lacon's model, and no doubt it works rery quickly as a model. But the objections which I hare to offer to the contrirance are these. In the first place, if the pennants were worked with chains instead of ropes, I for one should decline to go in the boat at all. In the next place, if the ressel was going through the water (when we know the length of that pennant must be at least 4.0 feet, the poop of a line-of-battle ship being some 26 feet above the water, must allow for the length of the darit), I have some doubt in my orm mind when the boat was shored away from the side of the ship, if we should not have the end of the pennant in the serew-mell. Another remark I hare to ofler is this. It is proposed to have a number of sheares in the head of the darit to take the nip of the pennant. Now; although the objection to the chain is quite established in my mind, still, baring it rope would be also objectionable, inasmuch as rope is liable to swell; and in the next place, we know what a dead nip is, and the great objection which all naral Officers have made to Clifford's apparatus is, that rery dead nip, and the single pennant. I hare ecen Clifford's apparatus and Kgnoston's, as well as the old fashioned plan we hare in the Serrice. I hare constantly tried them, and I have been lowered both by Kynaston's and Clifford's apparatus myself, and on one, if not two or tlurec occasions, with Clifford's apparatus after rainy weather; the ropo having been made of softened hemp, was found to hare swelled tremendously. On the other hand, tho objection to the Kynaston's plan is the manner of frecing, which the man has to do in the boat, and as I have seen myself, the boat has been suddenly frecd six feet abore the water. This inrention of course would free itself from the darits, prorided it rendered, which I think somewhat doubtful, at all times; homerer, if it is rope, and does render, some of the boat's crers nould hare possibly a rery serere blow, not to mention the fouling of the oars. The model works rery welk and rery prettily, but whetler the plan would work with a heary line-of-battle ship's or one of the iron-clad's cutters and 14 men in it, is, I think, somewhat doubtful ; at least I should like to see it rerificd before I would allow it. I think the objections which I hare raised to the plan have some reight. It certainly has all the faults but one of that of Clifford, and I think it has an extra one of its own, which to my mind would be impossible to orercome.

Colonel Strasige: May I ask whether this plan has been tried in the Royal Nary?

Captain Welcs: It has not to my knowledge.

Captain Bacroor, R.N. : I feel diffdent about saying anything, but I hardly understand that principle of lowering, whether it is in the way of Clifford's or not; but from what $I$ understand, those pennants are rore in the boat, and they are brought on board and require a certain degree of manipulation, and that one man in the boat cunnot let go the apparatus at once. I do not know whether I an right?

Mr. Strruixg Lacos : It is let go on board the ship, and not in the boat at all.

Captain BALFovn: The principle to be desired is, that the boat shonld be reliered when she touches the water. In Clifford's plan I think you cannot reliere the boat till she sheers. I do not know much about Kynaston's plan, but it has a quantity of gear, and you do not relieve the boat at once. I lave a plan of my own, which I am sorry I cannot bring formard in the short time allowed to me to-night. That plan is, that directly the boat touches the water, she is reliered without all that supernumerary gear, with the old tackle and fall, and without any gear but what 
is contained in the bottom of the boat. I hope I shall be able to bring the whole thing before you very shortly.

Captain Freyaxtre, R.N.: One thing, I think, has been made excecdingly clear, namely, that it is casier to destroy than to construct. I hare ceen Clifford's and Kynaston's, and we have now, had Mr. Stirling Lacon's plan described to us; at tho same time I am not at all inclined to give up the idea of obtaining something rery superior to the present Serrice plan. I quite agree with $M$ r. Stirling Lacon in what ho said as to the question of lowering, but $I$ think he rather understated the case. Io said for instance, we must have two men in the boat, tro men lowering the falls, and two men secing the falls clear, and that makes six men. Now ererybody is perfectly aware that at least there must be a serenth to secure anything like safe lowering, and that is the most important of all, the Offeer or man who sees to the hoat being lowered, who is looking orer the side and sags, "Hold on the after fall," and so on. Under those circumstances I think we certainly should not stop short of somo system which is supcrior to that, and I renture to think Mr. Stirling Lacon is also perfectly right in the riew which he takes, which is that something better for lowering must be had than the boat's falls. I think that is a sine quâ non. I think, amongst the dangers and accidents which have happened in lowering bonts, the most fertile of those dangers is the jambing of one of the falls. I think it is quite unnecessary for me to mention that, to an Officer who can gire such a good opinion on the subject as no doubt jou will jourself, Sir (referring to the Chairmaa). That is then one thing which we must guard against. Viewed from that stand point, I must confess tho praise which has been lavished upon Kynaston's is, to my judgment, rather undeserred. If the fall jambs, Kynaston's is a failure; therefore, if it be a necessity that we should hare something rhich does not lorrer by the falls, why re must put Kynaston's out of court. Then we come to arrangements such as Clifford's and Mr. Stirling Lacon's. Now I am afraid Mr. Lacon's was pretty well cut up, to use the common expression, by Captain Wells. Captain TVells mentioned sereral objections, but an additional one occurs to me, and that is, that in unreering the small lend-line which has to pass round sereral sheares, the probability is the small leadline will jamb between the sheare and the darit, and if that is the case, it strikes me we shall hare the boat broadside on and capsized. I hare paid some little attention to a good many of the boat-lowering apparatus, and there is no doubt, as has been stated, that the soft Manilla rope used in Clifford's will occasionally swell and jamb. All of us who are Eailors must at least recollect certain occasions on which this has taken place; $I$ can recall one or two in my own experience, and other Officers will no doubt be able to recall cases of the kind. Another objection is, that tho pennants are only of a certain length, which is supposed to be sufficient to allow the boat to reach the mater. No doubt if a ressel gets stranded high and dry, and you mant to lower a boat by Clifford's plan, you will tind perhap 3 the boat will be a considerable distance abore the water, and Clifford's apparatus will be more or less a failure. But I do think the objection made to lowering by Clifford's plan because it has to be done by one man in the boat, has been made rather too much of. I think the instances of lowering by Clifford's hare been most successful as a general rule, where the pennants have been properly looked after, and hare not been allowed to swell, and where consequently they hare not jambed, and this can easily be ensured against, I fancy, by keeping the boats always hung by the tackles with merely a slip which can bo knocked off the instant you hare got into the boat. Under those circumstances, no strain being on the pennants, if they are looked to frequently, they will not swell or jamb. The boat can then be lowered with perfect safety, and I. renture to say, though there are objections to it, yet on the whole with due deference to the opinion of the Committec on boat-lowering, that Clifford's arrangement has proved itself to be the most perfect of all those that hare hitherto been tried. At the same time, I am rery glad tlat Mr. Stirling Lacon has brought this before the "publie," as lie is pleased to call us, and I hope it will continue to be rentilated, and that we shall hare something which is a great deal more perfect than anything which has hitherto been placed before us.

Mr. Hexwood : I should like to ask MIr. Lacon if he can explain in what way Hill's lowering apparatus failed? From what I remember of the plan when Mr. Hill zead his paper here, I can see no possiblo way by which the boat could be disengaged, 
unless it was disengaged by the man in tho boat. As regards the fall jambing, if one fall jambs, the other jambs also by the arrangement of the falls, by a system of rollers inside the tulwarks of the ship, so that one cnd of the boat will not be lowered withont the other is lowered, but if there is a bigk in one fall, that will stop both going; they both run or they both jamb.

Captain Coons, R.N. : Sir, whenerer I hear of a new invention, and the probabi' lity of its succes or non-success, the first question I ask myself is, "How much more trouble is it going to gire?" because I have obserred generally that in rentions which are now and successful, generally get rid of some existing trouble-they supersede something. Usually when they do not supersede anything, but add an extra trouble, I find the inrention does not go domn rery well. Objections liare been made to Clifford's apparatus, for instance, which are no doubt sound and good as far as they go, but I hare always taken that the real objection to it was, this extrit frouble. I should inagine that the stme objection would lie against Mr. Stirling Lacon's plan; there is a certain amount of hooking and unhooking of the falls, a certain reeving and unreering of the pennants, all things wlich occupy time and gire trouble, and we have a great deal too much trouble, and not too much time usually on board ships, cspecially on board merchant ships. I hare always thought with respect to boat-lowering apparatus, that a really good one must jossess three qualitics: 1st, the boat must be lowered square by one man; 2nd, the same apparatus which is used to lower must also be used to hoish up; and 3rd, the water, and nothing but the vater, should discngage the boat. So soon as we get those three qualities combined in a boat-lowering apparatus, we shall hare what we want. I can only say that I hare not secn as yet moro than two of these three qualities in any boat-lowering apparatus. We hare here in Mr. Stirling Lacon's plan the one man lowering the boat; so far I should say that is good. But the water does not detach the boat; on the contrary, the boat may be lowered half way down, may be met bra sea, and dashed against the ship's side witl slack tackles, it being impossible to disengage her. She may then come down witl a jerk, as we know will happen, and men may be thromn out by that jerk. In Clifforl's, in the same way you had precisely the same defect, but of course Mr. Stirling Lacon's, so far as it gocs, is better than Clifford's, inasmuch as the work of tho one man is done inside the ship, instead of in the boat, which all admit to be an adrantage. Both Clifford's and Mr. Stirling Lacon's cujoy the adrantage of the bont coming down square, which is a rery important matter. Now Irynaston's plan does not enjoy that adrantage of coming down square. It does not detach on reaching the water, but it is rery nearly the same thing, because it can be detached at any moment, which is not the case with either of the other tro. But Iynaston's, os. Captain Fremantle has rery properly remarked, possesses that rery great disadrantage, that there is the chance of jambing the falls, and one fall being lowered and the other lield on. Those aro three plans before us. If I am right in supposing that tho three qualities I hare mentioned are those necessary for a perfect boat-lowering: apparatus, it is quite clear that neither of those three plans are perfect, and $I$ presume that until we get a perfect plan, no committce that erer sat would recommend the doing away of that which, howerer ineflicient it may be, has been in use for such a number of years.

Mr. Gejpec : No ono can question the noblo object Mrr. Stiring Lacon has in ricw in bringing formard this plan, but still I must confess that it has its defeiencies, though perbaps in minor points. One point which has been orerlooked is this, that as soon as the boat reaches the water, it sheers off, and brings these chains into a position in which they do not fairly run over the sheares; a kink, or anything of that kind might occur, and a stoppage take place in the sheare, or davit. These things are likely to happen with this apparatus, and that is only one of many other objections which can be raised against it. The last speaker mentioned three requisites for any boat-lowering apparatus, the first being to have one man to lower from inboard. Now this can be done with common falls, by meaus of a simple apparatus, one man can at the same tine sec tho boat, ond, by means of a lerer, allow the boat to go down on an eren kecl at any speed, aud at any moment he may choose. I can show that at any time, and if permitted will bring the whole thing before this Institution. The sccond requisite was that the boat should bo disengaged as coon as she reaches the water. This, too, can be.rlone; a certain form of hook can be attached to the 
eristing block, and be made so as to disengage itself as soon as the boat is completely waterborne, not like Hill's, which is not always discngaged when the boat reaches the water, since there are cases in which the strain is constantly kept on the hook, eren after the boat is allost, and the hook cammot disengage. The only way it does disengage is when the ware strikes the boat, and suddenly disengages the slings from the hooks. I say that is the only way in which it can be done, and it is admitted by people who have tried it, that when a boat is lowered in smootl mater, with good way on the ship, as soon as the boat reaches the water, the strain is bept on the hook, and the hook does not disengage. All this can be aroided by a rery simple contrirance. The boat, as she becomes waterbome, disengages herself, and the hook can be eo constructed that when the boat haugs on the falls, it requires the pull of the weight of the boat to disengage it, or you may make it so that the pull of half the reight of the boat will disengage it. She docs not disengage until she is completely, waterborne. I am prepared to show this. Now comes a third point, that of using the same tackle for raising the bont. This also can be done, it is simply a question of cost. To the arrangement which I have derised for lowering the boat, a small windlass conld be attached, enabling, according to the weight of the boat, one or several men to hoist her.

Mr. IILL: I am not getting up here to criticise or find fault in any way with any apparatus, but, quito unexpectedly to myself, I heard'my name mentioned by Mr. Lacon, in his paper, in reference to my inrention which has been tried on boaed the "Challenger." I hare not met with one sailor who could adrance any great objection against the inrention, and $I$ rise here now to ask if anj gentleman who is lere cam point out any faults therein. I may say. I hope soon to hare a model which erery one may inspect in this Institution. Now in order to show you that the loss of the "Challenger's" boat from the davits must not be considered adrerse to the inrention, I will real you a copy of the report which Captain Nares sent to the Admiralty. "The port quarter boat fitted with Messrs. IIill and Clark's Patent Disengaging Hooks, had been kept ready for immediate lowering, with the safety pins out. As the men were about to enter the boat to replace and sceure them, a rery henry sea, combined with a lurch, dipped her in the water. The hooks immediately slipped (as is Mr. IIill's intention), and the boat was washed from the darits. Before steps could be taken to recorer her, the foremost thwart to which the boat rope was attached, was carried inay, probably in consequence of the boat being struck against the elip's counter, and she drifted astern, and was lost.

"Alliough this boat was undonbtedly lost in consequence of the falls behng fitted with Hill and Co.'s disengaging hooks, I still think them most raluable, and on secing the boat ready for lowering with the safety pins in, which prevents the falls unhooking, I wade the men try to draw them out, and finding that they could not do so without first using a marline-spike to twist them round, $I$ ordered them to be kept out. The pins were probably in the present case a little large and stiff, through being. gralranized."

The galranizing was done at the last moment, and that accounted for a little stiffness. Captain Nares ordered me to fit another bont with the apparatus, and the "Challenger," I am happy to say, has arrived at Gibraltar with that apparatus on board, and no account of any further accident lias been recorded.

In conclusion I may add the "Challenger" is not fitted with our lowering gear, but simply with our patent disengaging hooks. The lorering gear enables one man to lower the boat upon an eren keel by the old falls, without fear of accident.

The Cirmmons: I beliere it is not the duty of the Chairman to criticise, but rather to try and make matters as pleasant as possible for all partics. I wish, howerer, to make one remark with regard to the old Service plan, because I think it will be uscful. If boats are lowered into the sea in the manner just displazed to us, there would be great difficulty in unhooking the tackles, eren if the boat eame down fairls; but the "Phacton" laring been alluded to, I must tell jou that in that ship we always had a strong boat's painter passed forward along tho ship, and stopped up to the main chains, just sufficient/y long, so that when the boat touched the water the painter caught the boit and kept lier from going aft, so that the men in the boat could unhook the tackles. With this precaution I have nerer had any hesitation in smooth water in lowering quarter boats when the ship had headway. I beliefe that. 
another matter has been rery much neglected. We hare been fitting our quarter boats, which is quite necessary, but we hare neglected our stern boat. I beliere a boat can be let go from the stern and let run on MIr. Lacon's or any other similar plan. It is generally a smaller boat, and therefore I hare found that by haring the stern boat fitted so that she could be let run with a pennant in the manner just described, it can be done with more safety than from the quarter, because there is no doubt that where a boat is slipped from the tackles, either on this or any other plan, strict attention must be paid to the roll of the ship, which is not an easy matter, and if any mistake is made in carrying out theso complicated arrangements, the consequences may be rery serious. One or two remarbs hare been made which $I$ may just notice. One was with regard to letting these chains drop on the men. I do not think much of that, nor do I think that the chain could get into the screw well. I do not think that the chain would injure the men, but if it did, you might splice a rope on to the end of the chain. I dare say it rould not be pleasant to hare it on one's head, but I do not think it rould injure a man, and Jack does sometimes stand a good crack without earing much about it. Then it was said that the lead-line would interfere, because if the lead-line happened to jamb, the boat would be smamped by it. I do not think the lead-line would hold on. I think it rrould break immediately such a strain came upon it. I do not know that an Officer is erer placed in a position of greater responsibility than he is when he is called upon in bad weather to decide whether to lorrer a boat after a man who has fallen orerboard, because the question is this, whether you are not going to lose perhaps cight. or ten men in the endcarour to save one. I have heard what my friend Mr. Stirling Lacon has eaid, and I should really prefer his plan to either Kynaston's or Clifford's. I have nerer udopted cither of those plans, because I considered that they were just as likely in the long run to cause accidents as they were to prerent them; that was my opinion. For that reason I always fitted my boats in the ordinary way. I consider Mr. Lacon's a very sensible plan for smooth water, but I see the objection of letting go when the ship is not on an cren keel. If the ressel happened to be rolling heavily, the boat might be let go at eome distance from the water, which would be objectionable. This question of submitting plans by molels is, I think, most unsatisfactory, and few have the opportunity of haring them put to actual test. The question of saving life at sea is one to which many may remember my namo has been attached for a very great number of years. I haro always had it on my thoughts. I think a good deal could be done to sare life at sea, and I think rery little has been done. I licar that in the United States they hare an association for the purpose of promoting the safety of life at sea, and that that association las done a great deal of good. $\bar{I}$ am happy to say an association of a similar kind has been formed in England, and will be heard of in a rery short time. I trust everybody who can, who has this great and important question at heart, when they sce this opportunity afforded them will come forward to assist that association to promote safety of life at sea, by putting a model merchant ship into the water to contain all the best means and appliances by which life can be sared, whether it be for the lowering of boats, or for saring the brealing of chain cables, or prerenting collision, which is the most important thing of all. We have railways on shore; we lave the Board of Trade enforcing railway breaks, not only that, but enforcing the adoption of the rery best break that can be procured. At eca we hare ships running with a serew propeller which has no power whaterer to arrest the progress of the ship, and until we do get a break of some kind to our ships we shall nerer stop collisions, because if the helm happens to be put the wrong way, on the ship must go, and she must go orer ererything in her way.

Br. Stincisa LAcoN : I ought to have spoken before Admiral Elliot, in answer to Captain Wells, who spoke of the danger from the chain falling on the men. Now there is no necessity to hare a clioin. You may have rope penuants. Then, as to the fouling of the serew, I should think the first thing the Commanding Officer would do in the event of lowering the boat would be to stop the screw. With regard to Mr. IIill's remarks, he will recollect that I stated Admiral Richards had written to me saying that it was through no fault of MIr. Hill's plan that the accident took place.

The Cramprax: I am sure we are greatly obliged to Mr. Lacon for haring brought this subject formard in the very able manner he has done. 


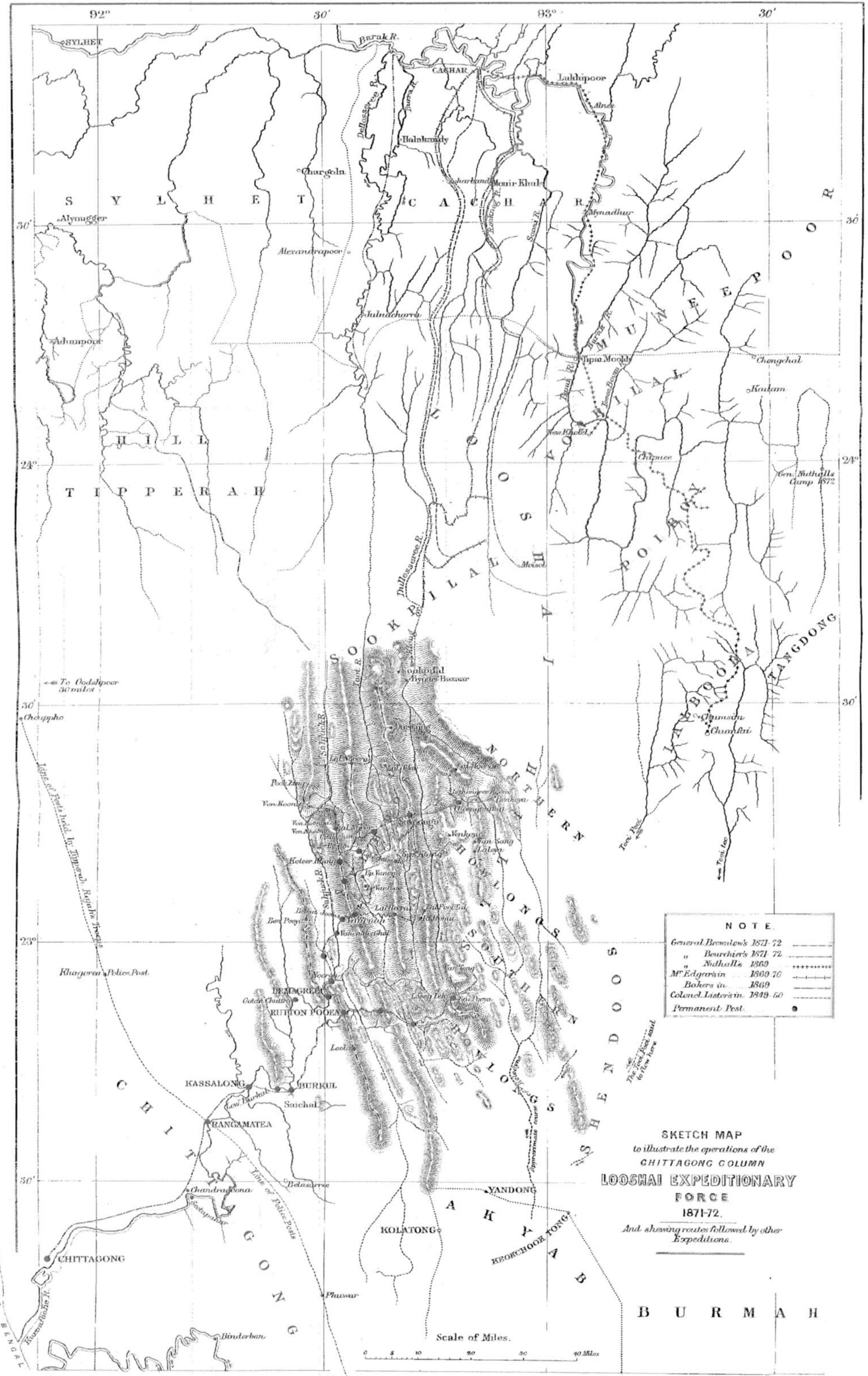

